\title{
Psychosocial impact of chronic infection with hepatitis B virus on British patients
}

\author{
A S F LOK, D J VAN LEEUWEN, H C THOMAS, AND S SHERLOCK \\ From the Academic Department of Medicine, Royal Free Hospital, London NW3 IQG
}

SUMMARY The effects of chronic infection with hepatitis B virus (HBV) on the lives of 40 British patients were studied by means of a questionnaire. The aspects considered were: social, sexual, and family life, physical and psychological health, and work. Thirty six patients considered their lives to have been affected, nine mildly, 14 moderately, and 13 severely. The aspects of life most affected were: sexual (13), psychological (11), physical (5), work (3), social (2), and family (2). Most of the problems encountered were related to infectivity. The availability of vaccines against HBV and of successful antiviral treatment have solved some of the problems, but it remains important for the medical profession to be aware of the multifaceted impact of the carriage of HBV.

\section{Introduction}

There are thought to be 200 million carriers of hepatitis B virus (HBV) throughout the world. They are a potential source of infection for others, and some develop cirrhosis or hepatocellular carcinoma..$^{1-5}$ Most remain asymptomatic or only mildly symptomatic for many years, often until they die of another cause. The psychological, sexual, and social impact, however, begins from the moment they are pronounced carriers of the virus. This problem is often more difficult to handle than the physical illness itself. In this study we have attempted to identify some of these problems to enable us to offer more appropriate advice and to help such patients to cope with their problems.

\section{Patients and methods}

We sent 52 carriers of HBV living in Britain and attending this hospital a questionnaire enquiring into the presentation of the infection, the patients' knowledge of the mode of its acquisition and the extent of its secondary transmission, and their own assessment of the severity of its effects on various aspects of their lives. Each questionnaire was accompanied by an explanatory letter and was returned, unsigned, by post.

Address for reprints: Dr A S F Lok, Department of Medicine, Queen Mary Hospital, Hong Kong

Accepted for publication 27 September 1984

\section{Results}

Forty $\mathbf{( 7 7 \% )}$ questionnaires were returned. No features distinguished those who responded from those who did not. Three patients were women and 37 were men. Their ages ranged from 22 to 63 (median 35) years. The known duration of hepatitis B surface (HBs) antigenaemia varied from 1 to 10 years, with a median of $2 \cdot 5$ years.

\section{MODE OF TRANSMISSION AND INFECTIVITY}

Nineteen patients (18 of whom were homosexual or bisexual men) thought that they had acquired the virus sexually. Six probably acquired the infection parenterally: two through intravenous drug abuse, one from multiple transfusions, and three were health care workers with a history of needle pricks. Fifteen patients had no idea of the source of infection.

Thirty one patients were not aware that they had ever transmitted the infection, and nine (six homosexual, two bisexual, and one heterosexual) realised that they had probably infected one to four people.

IMPACT OF CHRONIC INFECTION WITH HBV Only four patients thought that chronic HBV infection had had no effect on their lives. The remaining $36(90 \%)$ considered themselves to have suffered, nine mildly, 14 moderately, and 13 severely. Aspects of life most affected were sexual (13), psychological (11), physical (5), work (3), social 
(2), and family (2). All the patients were worried about infectivity and the effect of HBV on their livers and on their life expectancy.

\section{PSYCHOLOGICAL ASPECTS}

Thirty four patients experienced depression, 22 felt isolated, especially initially, and 15 had feelings of guilt. Three had sought, and four considered seeking, psychiatric help.

\section{Sexual life}

Twenty three (58\%) patients were homosexual, eight $(20 \%)$ bisexual, and nine (22\%) heterosexual. A third of them felt that the greatest impact had been on their sexual lives. The three who reported no influence on their sexual lives were all homosexuals with steady partners, two of whom were immune to $\mathrm{HBV}$ and the third was an HBV carrier.

Twenty four $(60 \%)$ patients were either married or had steady sexual partners, and all were aware of their HBV infection. The HBV states of the spouses or partners were: carrier (3), immune (14), susceptible (4), and unknown (3). Six of these 24 patients felt inhibited about having sexual intercourse with their partners. Four had been deserted by their partners because of their HBV carrier state.

Twenty four patients (two heterosexual, five bisexual, and 17 homosexual) had two to 250 (median 20) casual partners a year. This number had remained constant in six, but in the others it had decreased. Of these 24 patients, five never informed potential sexual partners of their infection with HBV, whereas six claimed that they always did, and the remaining 13 only did so at times. Of the latter 19 patients, 10 had experienced refusal of sexual contact but still disclosed their HBV state. The sexual practices of the homosexuals varied widely and usually remained unchanged. Eight, however, reported reduced incidence of anogenital intercourse, oral kissing, and orogenital contact.

\section{Social and family lives}

Most patients remained socially active, but seventeen $(43 \%)$ admitted having withdrawn themselves because of fatigue and fear of making new friends. Most $(24(60 \%))$ did not feel inhibited about letting their close friends know that they were HBV carriers, but many did not feel obliged to do so. Six patients had experienced rejection by some of their friends.

Only eight of the 40 patients were married, and all their spouses were immune. The spouses were usually sympathetic and supportive. Family life was affected appreciably for only two patients; one felt rejected by his wife, who considered him unclean; the other, a young woman, was worried about passing the infection to any children she might have. Her subsequent refusal to have children had strained her marriage.

\section{Work}

This was not usually affected. Nevertheless, seven patients had had to change their careers. Two had done so mainly because of fatigue. The remaining five were considered to be medically unfit. Three were not accepted after a pre-employment medical check for the jobs of intensive care nurse, police officer, and army pilot; the first two had remained unemployed for six and 24 months. Two patients had had their contracts terminated; one was a renal dialysis nurse and the other a production manager for a musical group. Five patients complained of hostility from and rejection by their workmates.

\section{Physical health}

Twenty four $(60 \%)$ patients were asymptomatic. Only five $(13 \%)$ considered their health to have been seriously affected.

Because of their possible infectivity, two patients had been refused minor operations, and one patient with debilitating avascular necrosis of the hip had had his operation postponed repeatedly. Eighteen $(45 \%)$ patients had been refused dental treatment, and $17(43 \%)$ could only obtain treatment from hospital dentists. Treatment was often delayed and restricted to emergency care and extractions.

\section{Discussion}

This study concerned carriers of HBV attending the Royal Free Hospital in London. In view of our interest in antiviral treatment, it was biased towards young patients whose serum contained hepatitis e antigen $(\mathrm{HBeAg})$ and who had high levels of viral replication. This accounts for the preponderance of young homosexual men, their concern over infectivity, and the rarity of patients with end stage chronic liver disease. Young homosexuals form a large proportion of $\mathrm{HBV}$ carriers in the indigenous population in Northern Europe and the United States. ${ }^{6-8}$ The impact of the carriage of HBV in areas where it is highly endemic, such as South East Asia and Africa, is obviously different.

Most of the problems are related to infectivity. Dentists and surgeons are reluctant to treat patients who have hepatitis B surface antigen (HBsAg), in spite of the official view from the British Dental Association that full treatment should be available. Although there is no legislation restricting the employment of HBV carriers, five of our patients were deemed medically unfit for their jobs. This is understandable in the case of dialysis nurses, but the risks in other areas of employment are minimal. In 
addition, no differentiation is usually made between $\mathrm{HBe}$ antigen and $\mathrm{HBe}$ antibody, which differ considerably in their infectivity. There is no reason, provided adequate personal hygiene is ensured, that HBV carriers without serious liver disease should not engage in any occupation.

Insufficient knowledge and undue anxiety about the transmissibility of the virus may lead to the isolation of carriers. There is no evidence that the virus can be transmitted by droplet inhalation, and the infectivity of other secretions is not certain. ${ }^{9-13}$ Hepatitis B surface antigen (HBsAg) can be detected in the saliva and semen of HBV carriers, but these $22 \mathrm{~nm}$ spheres alone are not indicative of infectivity. ${ }^{14}$ With molecular hybridisation techniques, which are a more sensitive measure of HBV replication and hence infectivity, ${ }^{16} 17$ small amounts of HBV-DNA sequences have been detected in the saliva and semen of some HBV carriers who have high levels of virus in the serum (Karayiannis $P$, Novick DM, Lok ASF, et al, unpublished observation).

The availability of safe and effective vaccines should solve many problems. ${ }^{18-21} 24$ When dentists and surgeons are vaccinated essential treatment will become available to patients with HBV. Vaccination of spouses and other regular sexual partners relieves the psychological strain and inhibitions on sexual life. The routine vaccination of all homosexuals must be considered. Many HBV carriers are asymptomatic and unaware of their infectivity, and even those who realise that they are carriers may not always inform their potential sexual partners. The risk of acquiring the infection is very high in those who lead a promiscuous life. Indeed, 5-10\% of the homosexual population are carriers, although $40-50 \%$ are immune to HBV. ${ }^{82}$ For cost effectiveness all those who are susceptible to the virus should be vaccinated. ${ }^{2324}$

The treatment of chronic infection with HBV is developing rapidly. There have been recent reports of successful antiviral treatment, elimination of infectivity, and biochemical and histological resolution of liver disease. ${ }^{25-29}$ In one study $50 \%$ of the patients who were treated with interferon had long term responses. ${ }^{30}$ It is thus possible to treat patients infected with $\mathrm{HBV}$ and enable some of them to return to a normal life.

We thank our patients for their cooperation in this study and Miss $M$ Walsh for her secretarial help. ASFL is supported by the University of Hong Kong.

\section{References}

1. Viola LA, Barrison IG, Coleman JC, Paradinas FJ, Fluker JL, Murray-Lyon IM. Natural history of liver disease in chronic hepatitis B surface antigen carriers: survey of 100 patients from Great Britain. Lancet 1981; ii:1156-9.
2. Hoofnagle JH, Seeff LB. Natural history of chronic type B hepatitis. In: Schaffer F, Popper H, eds. Progress in liver diseases. New York: Grune and Stratton. Vol VII. 469-78. 1982

3. Dudley, Scheuer PJ, Sherlock S. Natural history of Australianantigen associated chronic hepatitis. Lancet 1972; ii: 1388-93.

4. Beasley RP, Hwang L-Y, Lin C-L, Chien C-S. Hepatocellular carcinoma and hepatitis B virus; a prospective study of 22707 men in Taiwan. Lancet 1981; ii: 1129-33.

5. Prince AM, Alcabes $P$. The risk of development of hepatocellular carcinoma in hepatitis B virus carriers in New York. A preliminary estimate using death records matching. Hepatology 1982;2:15S-20S.

6. Szmuness W, Harley EJ, Ikram H, Stevens CE. Sociodemographic aspects of the epidemiology of hepatitis B. In: Vya GN, Cohen SN, Schmid L, eds. Viral hepatitis. Philadelphia Franklin Institute Press, 1978:297-320.

7. Szmuness W, Much MI, Prince AM, et al. On the role of sexua behaviour in the spread of hepatitis B infection. Ann Intern Med 1975; 83:489-95.

8. Schreeder MT, Thompson SE, Hadler SC. Hepatitis B in homosexual men: prevalence of infection and factors related to transmission. J Infect Dis 1982; 146:7-15.

9. Villarejos VM, Visona KA, Gutierrez DA, Rodriques AA Role of saliva, urine and faeces in the transmission of type B hepatitis. N Engl J Med 1974; 291: 1375-8.

10. Bernier RH, Sampliner R, Gerety $R$, Tabor E, Hamilton $F$ Nathanson $\mathrm{N}$. Hepatitis $\mathrm{B}$ infection in households of chronic carriers of HBsAg: factors associated with prevalence of infection. Am J Epidemiol 1982;116: 199-211.

11. Bancroft WH, Snitbhan R, Scott RM, et al. Transmission of hepatitis B virus to gibbons by exposure to human saliva containing hepatitis B surface antigen. J Infect Dis 1977; 135: 79-85.

12. Scott RM, Snitbhan D, Bancroft WH, Atter HJ, Tingpalapong M. Experimental transmission of hepatitis $B$ virus by semen and saliva. $J$ Infect Dis 1980; 142:67-71.

13. Alter $\mathrm{HJ}$, Purcell $\mathrm{RH}$, Gerin $\mathrm{JL}$, et al. Transmission of hepatitis B to chimpanzees by hepatitis B surface antigen positive saliva and semen. Infect Immun 1977;16:928-33.

14. Heathcote J, Cameron $\mathrm{CH}$, Dane DS. Hepatitis B antigen in saliva and semen. Lancet 1974; i:71-3

15. Feinman SJ, Kransnitoki O, Sinclair JC, Wrobel DM, Berris B. Hepatitis B surface antigen in saliva of HBsAg carriers. $J$ Lab Clin Med 1975;85: 1042-8.

16. Weller IVD, Fowler MJF, Monjardino J, Thomas HC. The detection of HBV-DNA in serum by molecular hybridisationa more sensitive method for the detection of complete HBV particles. J Med Virol 1982;9:273-80.

17. Berninger M, Hammer M, Hayer B, Gerin JL. An assay for the detection of the DNA genome of hepatitis B virus in serum. Med Virol 1982: 9:57-68.

18. Szmuness W, Stevens CE, Zang EA, Harley EJ, Kellner A. A controlled clinical trial of the efficacy of the hepatitis $B$ vaccine (Hepatovax B): a final report. Hepatologv 1981:1:377-85.

19. Francis DP, Hadler SC, Thompson SE, et al. The prevention of hepatitis B with vaccine: report of the Centers for Disease Control multi-center efficacy trial among homosevual men. Ann Intern Med 1982;97:362-6.

20. Crosnier J, Jungers P, Conrouce AM, et al. Randomised placebo-controlled trial of hepatitis $\mathrm{B}$ surface antigen vaccine in French haemodialysis unit: I, medical staff. Lancet 1981; 455-9.

21. Crosnier J, Jungers P, Courouce AM, et al. Randomised placebo-controlled trial of hepatitis $B$ surface antigen vaccine in French haemodialysis units: II, haemodialysis patients. Lancet 1981; i: 797-800.

22. Dietzman DE, Harnisch JP, Ray CG, Alexander ER, Holmes KK. Hepatitis B surface antigen ( $\mathrm{HBsAg}$ ) and antibody to HBsAg: prevalence in homosexual and heterosevual men. JAMA 1977; 238:2625-6.

23. Mulley AG, Silverstein MD, Dienstag JL. Indications for use of hepatitis B vaccine, based on cost-effective analysis. N Engl $J$ Med 1982; 307:644-52.

24. Adler MW, Belsey EM, McCutchan JA, Mindel A. Should homosexuals be vaccinated against hepatitis $B$ virus? $C_{C o s}$ and benefit assessment. $B r$ Med $J$ 1983; 286: $1621-5$.

25. Scullard GH, Pollard RB, Smith Ji., et al. Antiviral treatment of chronic hepatitis B virus infection. Changes in viral markers with interferon combined with adenine arabinoside. I Infect Dis 1981; 143: 772-83. 
26. Scullard GH, Andres LL, Greenberg HB, et al. Antiviral treatment of chronic hepatitis B virus infection: improvement in liver disease with interferon and adenine arabinoside. Hepatology 1981; 1:228-32.

27. Bassendine MF, Chadwick RG, Salmeron J, Shipton U, Thomas HC, Sherlock S. Adenine arabinoside therapy in $\mathrm{HBsAg}$ positive chronic liver disease: a controlled study. Gastroenterology 1981;80: 1016-21.

28. Weller IVD, Bassendine MF, Craxi A, et al. Successful treatment of $\mathrm{HBs}$ and $\mathrm{HBeAg}$ positive chronic liver disease: prolonged inhibition of viral replication by highly soluble adenine arabinoside 5'-monophosphate (ARA-AMP). Gut 1982;23:717-23.
29. Lok ASF, Weller IVD, Karayiannis P, et al. Thrice weekly lymphoblastoid interferon is effective in inhibiting hepatitis B virus replication. Liver 1984;4:45-9.

30. Lok ASF, Karayiannis P, Brown D, et al. A randomised study of the effect of adenine arabinoside monophosphate $(4$ or 8 week courses) versus lymphoblastoid interferon on hepatitis $B$ virus (HBV) replication. Hepatology 1983;3:865 (Abstract 268). 